\title{
Peningkatan Layanan Akademik Sekolah Sma BOPKRI 1 Melalui Aplikasi Registrasi Siswa Baru
}

\author{
Argo Wibowo ${ }^{\# 1}$, Antonius Rachmat Chrismanto*2, Yuan Lukito ${ }^{* 3}$ \\ ${ }^{\#}$ Sistem Informasi,Universitas Kristen Duta Wacana \\ Jl. dr. Wahidin Sudirohusodo no. 5-25, Yogyakarta \\ 1.argo@staff.ukdw.ac.id \\ ${ }^{* 2,3}$ Informatika, Universitas Kristen Duta Wacana \\ Jl. dr. Wahidin Sudirohusodo no. 5-25, Yogyakarta \\ 2anton@ti.ukdw.ac.id \\ 3 yuan@staff.ukdw.ac.id
}

\begin{abstract}
Abstrak - Seiring dengan perkembangan teknologi informasi dan komunikasi yang mampu mendukung proses input dan output data secara akurat dan efisien, maka penerapannya dapat dilakukan pada sistem layanan akademik khususnya dalam proses pendaftaran siswa baru. Di masa pandemi Covid-19 sistem pendaftaran dan penerimaan siswa baru sangat perlu dilakukan secara online di sekolah. Sistem pendaftaran dan penerimaan siswa baru yang valid akan menjadi modal awal dalam pelayanan pendidikan di sekolah. SMA BOPKRI 1 Yogyakarta sudah memiliki beberapa aplikasi seperti survey kegiatan sekolah, pengajuan proposal dan kinerja kegiatan, manajemen kegiatan guru, serta peningkatan mutu akreditasi sekolah yang merupakan hasil penelitian kerja sama dengan Universitas Kristen Duta Wacana (UKDW). SMA BOPKRI 1 Yogyakarta membutuhkan sistem aplikasi manajemen pendaftaran dan penerimaan siswa baru. Tim pengabdian FTI UKDW membantu dalam peningkatan layanan administrasi sekolah melalui hilirisasi Sistem Informasi Pendaftaran Siswa Baru (SiBaru). Aplikasi SiBaru dapat membantu calon siswa agar secara mandiri dapat menggunakan fasilitas pendaftaran tersebut. Para staff admin dan tata usaha juga dapat dengan mudah dan cepat mengolah data calon siswa baru. Program pengabdian ini meliputi beberapa tahapan utama yaitu: koordinasi antara tim dan mitra, kegiatan penyempurnaan aplikasi dan evaluasi terhadap program yang telah dilaksanakan. Hasil program pengabdian berupa penyempurnaan aplikasi SiBaru, pelatihan sistem kepada mitra, dan peningkatan kapabilitas penerimaan calon siswa baru oleh sekolah Dari hasil pengujian didapatkan tingkat keberhasilan sebesar $\mathbf{7 4 \%}$ untuk proses registrasi dan telah dilakukan perbaikan-perbaikan sesuai dengan hasil pengujian dan evaluasi tersebut. Program pengabdian kepada masyarakat ini masih akan berlanjut pada tahapan berikutnya yaitu pelatihan dan pendampingan mitra dalam implementasi sistem SiBaru.
\end{abstract}

Kata kunci-Pendaftaran Siswa Baru, Aplikasi SiBaru, Peningkatan Layanan Akademik, SMA Bopkri I Yogyakarta.

Abstract-Along with the development of information and communication technology that is able to support the process of input and output data accurately and efficiently, it can be applied to the academic service system, especially in the new student registration process. During the Covid-19 pandemic, the registration and admission system for new students really needs to be done online at schools. A valid new student registration and admission system will be the initial capital in educational services in schools. SMA BOPKRI 1 Yogyakarta already has several applications such as surveys of school activities, submission of proposals and activity performance, management of teacher activities, as well as improving the quality of school accreditation which is the result of research in collaboration with Duta Wacana Christian University (UKDW). SMA BOPKRI 1 Yogyakarta requires a new student registration and admissions management application system. The UKDW FTI service team helps in improving school administration services through the downstreaming of the New Student Registration Information System (SiBaru). The SiBaru application can help prospective students to independently use the registration facility. The admin and administrative staff can also easily and quickly process data for prospective new students. This service program includes several main stages, namely: coordination between teams and partners, application improvement activities and evaluation of programs that have been implemented. The results of the service program are in the form of improving the SiBaru application, training partner systems, increasing accessibility and ease of service for prospective new students, admin and administrative staff. The result of SiBaru's evaluation score is 74\%. Next step is mentoring and training SiBaru usage.

Keywords - Student Registration, SiBaru Application, Improvement of Academic Services, SMA Bopkri I Yogyakarta. 


\section{PENDAhUluan}

Pendidikan merupakan kebutuhan manusia yang sangat penting karena pendidikan mempunyai tugas untuk menyiapkan kemampuan Sumber Daya Manusia (SDM) bagi pembangunan bangsa dan negara. Kemajuan Teknologi Informasi dan Komunikasi (TIK) mengakibatkan perubahan dan pertumbuhan kearah yang lebih baik namun juga lebih kompleks. Hampir semua kegiatan manusia dapat dibantu oleh TIK termasuk dalam bidang pendidikan yang diimplementasikan di sekolah. Salah satu kegiatan yang dapat ditingkatkan layanannya dengan TIK adalah kegiatan pendaftaran siswa baru di sekolah.

SMA BOPKRI 1 Yogyakarta merupakan salah satu sekolah di Yogyakarta yang sangat memperhatikan penggunaan TIK di dalam seluruh kegiatan usahanya. SMA ini terletak di kawasan Kotabaru, Yogyakarta. SMA BOPKRI 1 Yogyakarta telah memiliki beberapa sistem / aplikasi berbasis TIK yang telah dikembangkan sebelumnya, seperti Aplikasi Survey Kegiatan Sekolah, Aplikasi Pengajuan Proposal dan Kegiatan, Aplikasi Manajemen Kegiatan Guru, dan Sistem Peningkatan Mutu Akreditasi Sekolah yang semuanya merupakan hasil penelitian dan kerja sama dengan Universitas Kristen Duta Wacana (UKDW). Saat ini SMA BOPKRI 1 Yogyakarta sedang berfokus pada peningkatan layanan kegiatan pendaftaran siswa baru.

Kegiatan pendaftaran siswa baru merupakan kegiatan rutin yang dilakukan oleh tiap sekolah pada setiap awal tahun ajaran baru [1]. Saat ini masih jarang sekolah di Indonesia yang menerapkan penerimaan siswa baru secara online. Seiring dengan perkembangan TIK yang mampu mendukung proses input dan output data secara akurat dan efisien, maka kegiatan penerimaan siswa baru juga dapat ditingkatkan layanannya menggunakan sistem berbasis TIK. Sudah selayaknya sistem penerimaan siswa baru secara online diterapkan oleh setiap sekolah, terlebih di masa pandemi COVID-19 ini. Pendaftaran siswa baru merupakan pintu gerbang masuknya siswa ke dalam dunia pendidikan. Sistem pendaftaran siswa baru yang baik akan menjadi modal awal dalam layanan pendidikan di sekolah. Hal ini sangat diharapkan dan difokuskan oleh SMA BOPKRI 1 Yogyakarta untuk meningkatkan pelayanannya.

Sistem pendaftaran siswa baru secara online merupakan sebuah konsep pendaftaran siswa baru yang terdigitalisasi, dapat diterima secara umum dan dapat diakses oleh setiap individu/calon siswa baru. Tujuan utama dari sistem pendaftaran siswa baru online adalah untuk meningkatkan efisiensi, mencegah dan mengurangi redundansi data, serta merapikan arsip data yang selama ini dilakukan secara manual dengan kertas atau sistem offline. Pendaftaran siswa baru saat ini di SMA BOPKRI 1 Yogyakarta sudah online namun masih sebatas penggunaan layanan pihak ketiga yaitu Google Form yang tidak terintegrasi. Hal ini perlu ditingkatkan karena penggunaan layanan pihak ketiga masih memiliki kekurangan bila dibandingkan menggunakan server dan layanan internal. Hasil penelitian menunjukkan $63 \%$ pengguna merasa khawatir file data pribadi mereka akan disimpan di pihak ketiga [2].

Saat ini sudah banyak dikembangkan aplikasi penerimaan siswa baru seperti yang dilakukan oleh Rapiansyah untuk siswa SMK [3] dan oleh Putra dan Dapiokta [4] untuk siswa SD. Beberapa penelitian seperti yang dilakukan oleh Pratama dkk [5] dan Dzulhaq dkk [6] menerapkan metode Simple Additive Weighting untuk membantu mengambil keputusan dalam proses seleksi siswa baru. Metode lain yang biasanya dipakai adalah TOPSIS seperti yang dilakukan pada penelitian Nata dkk [7]. Penelitian-penelitian tersebut dilakukan pada sekolahsekolah yang memiliki kebutuhan dan kriteria penerimaan siswa baru yang berbeda.

SMA Bopkri I Yogyakarta bekerja sama dengan Fakultas Teknologi Informasi (FTI) UKDW dalam kegiatan penelitian sekaligus pengabdian kepada masyarakat. Kegiatan pengabdian yang dilakukan adalah melakukan penyempurnaan aplikasi sistem pendaftaran siswa baru secara online yang diberi nama SiBaru (Sistem Informasi Pendaftaran Siswa Baru) dan pelatihan manajemen sistem tersebut setelah implementasi dan pengujian berakhir. FTI UKDW menugaskan tim pengabdi yang terdiri dari Argo Wibowo, Yuan Lukito, dan Antonius Rachmat C bersama dengan 2 orang mahasiswa untuk melakukan PkM tersebut.

Tujuan dari kegiatan PkM ini adalah melakukan hilirisasi terhadap aplikasi web Registrasi Siswa Baru (SiBaru) melalui pendampingan dan pembelajaran kepada staff admin dan tata usaha untuk mengolah data calon siswa baru secara mandiri. Selain itu, di dalam program ini juga akan ditambahkan program pendaftaran calon siswa baru untuk mendukung proses kegiatan pendaftaran calon siswa baru di SMA BOPKRI 1 Yogyakarta.

\section{Permasalahan}

Permasalahan yang sering terjadi dan masih menjadi sebuah permasalahan yang belum terpecahkan oleh SMA Bopkri I adalah waktu kompilasi data yang cukup lama, data hilang atau rusak karena masih disimpan secara offline [8], [9]. Redudansi data saat kompilasi data pendaftaran siswa baru juga menjadi salah satu masalah tersendiri. Hal ini dapat memperlambat kinerja staff admin atau tata usaha [10] dan tentunya juga menyita waktu maupun biaya bagi calon siswa baru [9]. Proses atau tahapan pendaftaran juga tidak bisa dilihat secara langsung oleh calon siswa baru. Hal ini menyulitkan calon siswa baru yang berasal dari luar 
kota, karena kabar penerimaan siswa baru tidak bisa dipantau secara langsung. Permasalahan berikutnya adalah jika sistem yang digunakan masih offline akan menyulitkan pendaftar yang berasal dari luar kota. Dan ketika sistem sudah online namun menggunakan layanan pihak ketiga akan menurunkan kepercayaan calon siswa baru karena menurut penelitian $63 \%$ pengguna merasa khawatir file data pribadi mereka akan disimpan di pihak ketiga [2].

Oleh karena itu pada kegiatan PkM ini berfokus pada bagaimana meningkatkan mutu layanan administrasi sekolah bagi para calon siswa baru dengan memanfaatkan TIK sehingga para calon siswa baru dapat secara mandiri mendapatkan dan menggunakan fasilitas pendaftaran siswa baru. Para staff admin dan tata usaha juga dapat dengan mudah dan cepat mengolah data calon siswa baru. Diharapkan dengan penerapan Aplikasi Registrasi Siswa Baru (SiBaru) yang mudah digunakan oleh para calon siswa baru ini dapat membantu memberikan informasi serta secara mandiri dapat melakukan pendaftaran siswa baru. Bagi staff admin dan tata usaha dapat meningkatkan mutu layanan sekolah di kegiatan pendaftaran siswa baru.

Dengan adanya program PkM ini diharapkan dapat membantu para calon siswa baru untuk mendapatkan informasi tentang fasilitas pendaftaran siswa baru di SMA BOPKRI 1 Yogyakarta. Selain itu, penggunaan Aplikasi Registrasi Siswa Baru (SiBaru) yang terintegrasi dengan fasilitas layanan sekolah lainnya dapat memberikan kemudahan bagi calon siswa baru untuk mendapatkan informasi sekolah lainnya selain pendaftaran siswa baru. Program ATTG ini merupakan hilirisasi dari Aplikasi Registrasi Siswa Baru (SiBaru) yang telah dikembangkan sebelumnya bersama dengan beberapa sistem lainnya. Melalui penggunaan aplikasi diharapkan mampu meningkatkan aksesibilitas dan kemudahan layanan bagi para calon siswa baru, staff admin dan tata usaha.

\section{METODE PELAKSANAAN}

Dalam pelaksanaan pengabdian masyarakat ini, metode, teknik pengumpulan data, teknik analisis, pengujian, dan pelatihan yang dilakukan adalah sebagai berikut:

\section{A. Koordinasi awal antara tim pengabdi dan mitra.}

Pada tahap ini antara FTI UKDW dan SMA Bopkri I melakukan koordinasi awal dan penentuan tim PkM yaitu Argo Wibowo, Yuan Lukito, dan Antonius Rachmat C. Ketiga dosen FTI tersebut ditugaskan oleh FTI untuk melakukan penyempurnaan aplikasi SiBaru, pengujian, dan pelatihan terhadap pihak sekolah.

\section{B. Penyempurnaan Aplikasi SiBaru}

Aplikasi SiBaru telah dikembangkan berdasarkan hasil penelitian antara FTI dengan melihatkan beberapa mahasiswa sebelumya. Pada PkM ini yang dilakukan adalah penyempurnaan sehingga tahapan detailnya adalah sebagai berikut:

\section{1) Requirements gathering tambahan}

Requirements gathering adalah tahapan pengambilan data kebutuhan dari pihak SMA Bopkri I. Berdasarkan rapat koordinasi berikut adalah daftar requirements tambahan:

i. Aplikasi registrasi siswa baru berupa aplikasi web, yang akan dipasang di server hosting milik SMA Bopkri I dan diintegrasikan dengan aplikasi sekolah yang telah dikembangkan sebelumnya.

ii. Aplikasi registrasi siswa baru dapat menerima pendaftaran dari calon siswa baru, dengan seluruh tahapan pendaftaran dapat dilakukan melalui website yang dikembangkan.

iii. Calon siswa baru dapat memasukkan data-data pribadi dan data nilai sekolah pada jenjang SMP atau setara.

iv. Aplikasi registrasi siswa baru dapat memberikan konfirmasi bahwa registrasi yang dilakukan oleh siswa telah berhasil dan seluruh data yang dimasukkan sudah disimpan di server SMA Bopkri I untuk digunakan sebagai bahan pertimbangan pada penentuan hasil registrasi.

v. Guru atau petugas sekolah yang bertugas dalam proses registrasi dapat melihat seluruh calon siswa baru yang telah mendaftar dan dapat menentukan hasil registrasi, yaitu diterima, ditolak atau ditunda.

vi. Calon siswa baru yang telah melakukan registrasi dapat melakukan pengecekan status pendaftaran, apakah sudah diterima, ditolak atau masih dalam proses.

\section{2) Analisis data requirements gathering}

Untuk proses registrasi siswa baru dibutuhkan sebuah database baru yang memuat informasi mengenai calon siswa, data registrasi, administrator dan status registrasi dari setiap calon siswa yang terdaftar.

\section{3) Penambahan desain aplikasi}

Aplikasi registrasi siswa baru akan diimplementasikan dalam bentuk website. Proses registrasi dibagi menjadi tiga tahapan, yaitu: pendaftaran calon siswa baru, penentuan hasil registrasi dan pemberitahuan hasil registrasi.

\section{4) Implementasi fitur tambahan pada aplikasi}

Proses implementasi dilakukan dengan pendekatan metode Agile yang sederhana, yaitu dengan cara implementasi fitur-fitur secara bertahap dan selalu dilakukan evaluasi dan perbaikan untuk setiap fitur yang telah dibuat.

\section{5) Pengujian dan evaluasi sistem}

Pengujian dilakukan dengan cara simulasi pendaftaran calon siswa baru yang dilakukan oleh beberapa responden, 
kemudian dilakukan evaluasi terhadap hasil pengujian dan dilakukan perbaikan jika diperlukan.

6) Pertemuan dengan mitra

Setelah proses pengujian dan evaluasi selesai, berikutnya adalah pertemuan dengan mitra untuk membahas mengenai hasil implementasi yang telah diuji dan dievaluasi. Perbaikan dan revisi bisa dilakukan jika diperlukan oleh mitra.

\section{7) Pengajuan HAKI aplikasi}

Pengajuan Hak Atas Kekayaan Intelektual (HAKI) dari sistem yang dibuat dilakukan setelah perbaikan dan revisi terakhir dari mitra. Untuk pengajuan HAKI juga diperlukan pembuatan dokumentasi sistem.

\section{8) System maintenance}

Setelah sistem registrasi calon siswa baru terpasang di server SMA Bopkri I, diperlukan pengelolaan sistem oleh administrator yang ditunjuk oleh sekolah.

\section{Pelatihan aplikasi kepada mitra}

\section{Pendampingan mitra}

Pendampingan mitra SMA Bopkri I Yogyakarta dilaksanakan selama Februari - November 2021. Sampai dengan tulisan ini dibuat pelaksanaan kegiatan telah berlangsung sampai dengan pengujian aplikasi SiBaru.

E. Koordinasi dengan mitra untuk tahapan penelitian dan pengabdian selanjutnya yang berkesinambungan.

\section{HASIL DAN PEMBAHASAN}

Aplikasi registrasi calon siswa baru (SiBaru) sudah berhasil dibuat dalam bentuk aplikasi website yang dapat diakses melalui browser di komputer maupun di perangkat mobile seperti smartphone dan tablet. Tampilan aplikasi SiBaru dapat dilihat pada Gambar 1 (diakses menggunakan komputer) dan Gambar 2 (diakses dengan menggunakan perangkat smartphone).

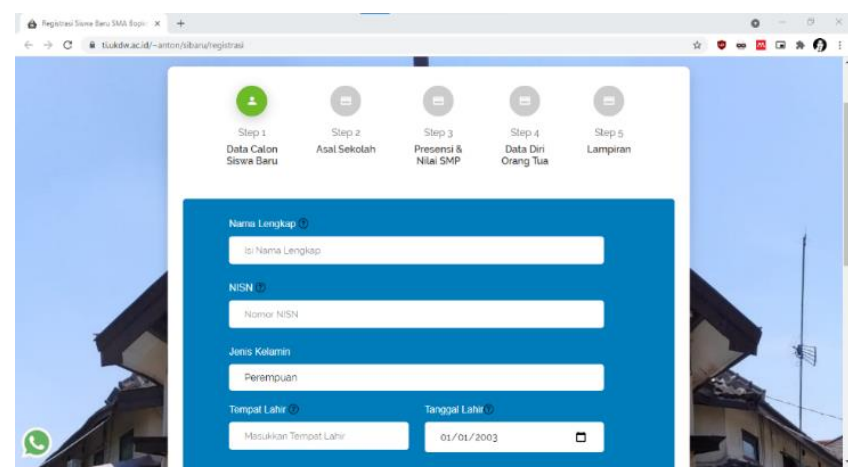

Gambar 1. Tampilan SiBaru jika diakses menggunakan browser komputer.

Calon siswa baru yang telah melakukan registrasi dapat melakukan pengecekan hasil registrasi melalui SiBaru. Contoh tampilan hasil registrasi dapat dilihat pada Gambar 3. Dengan demikian, seluruh tahapan registrasi sudah dapat dilakukan melalui SiBaru, sehingga diharapkan dapat memudahkan proses registrasi dari sisi calon siswa baru maupun dari guru atau tenaga administrator yang ditunjuk oleh sekolah.

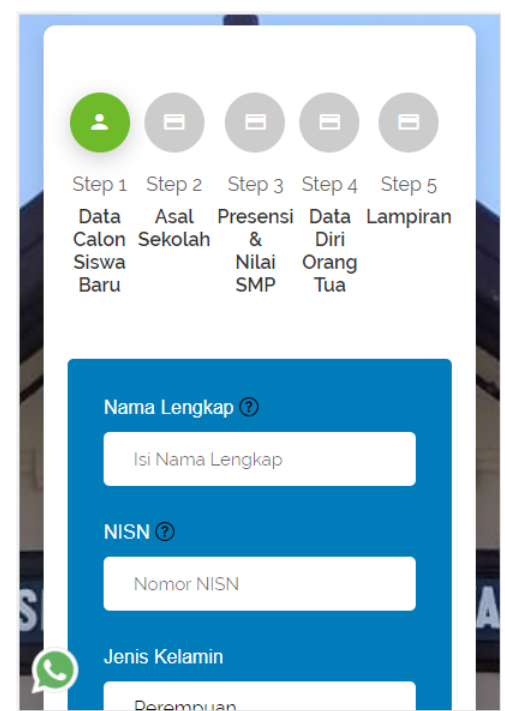

Gambar 2. Tampilan SiBaru jika diakses menggunakan browser smartphone.

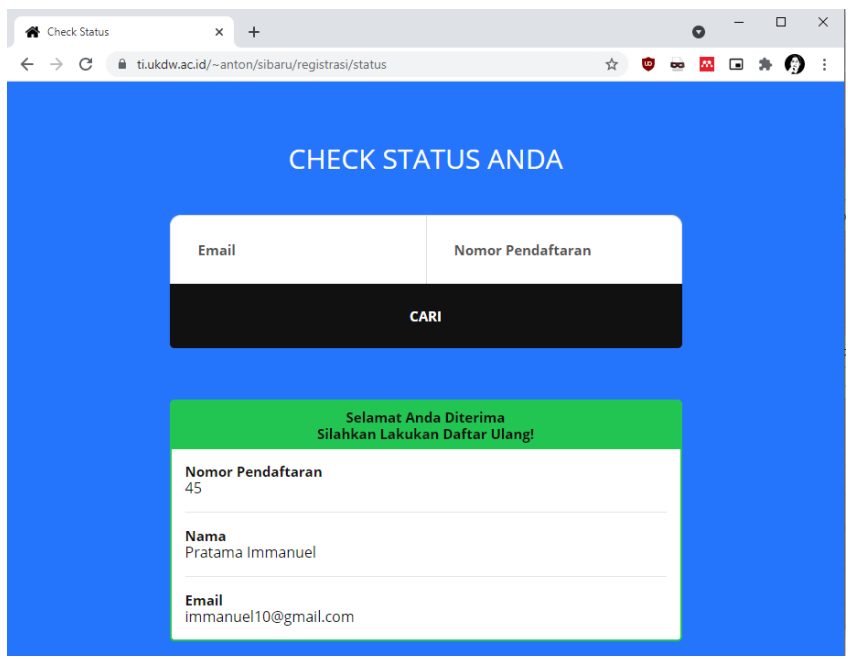

Gambar 3. Tampilan SiBaru pada pengecekan hasil registrasi.

Setelah implementasi berhasil dilakukan, tahap berikutnya adalah pengujian pada aplikasi yang dibuat sehingga meminimalkan kesalahan program ketika dilakukan implementasi kepada SMA Bopkri 1 Yogyakarta. 
Pengujian dilakukan dengan melibatkan 26 pengguna umum yang memiliki kesiapan berkas sesuai dengan masukan aplikasi SiBaru. Koordinasi awal melalui grup telegram yang dibantu oleh asisten mahasiswa seperti yang tampak pada Gambar 4.

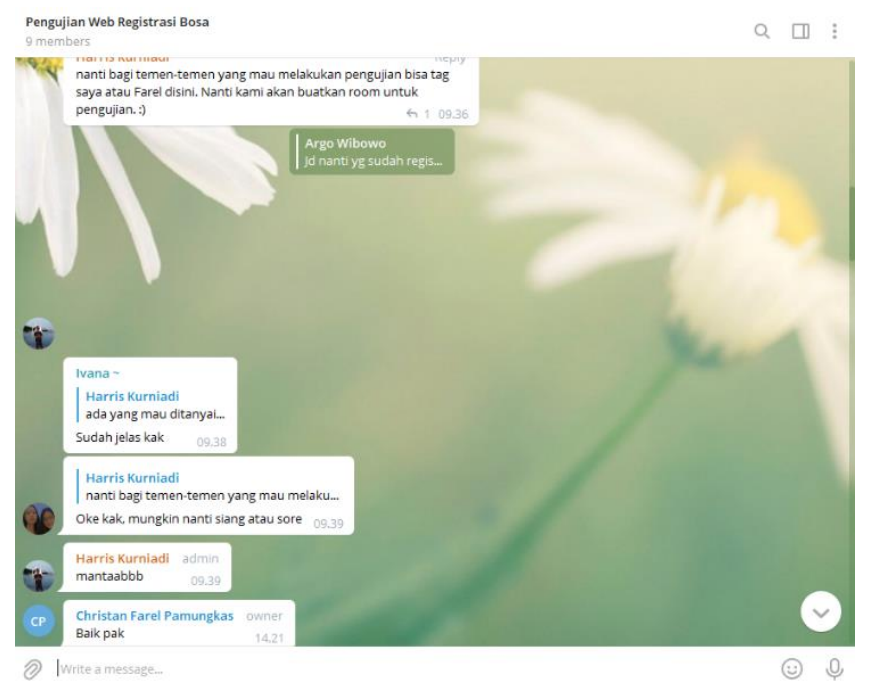

Gambar 4. Koordinasi Umum Tim Pengujian melalui Grup Telegram

Selanjutnya tim pengabdian mahasiswa membagi menjadi beberapa grup pengujian dan secara bergantian dipantau melalui media Google Meet seperti yang tampak pada gambar 5. Mahasiswa menunggu jika ada pertanyaan dari responden.

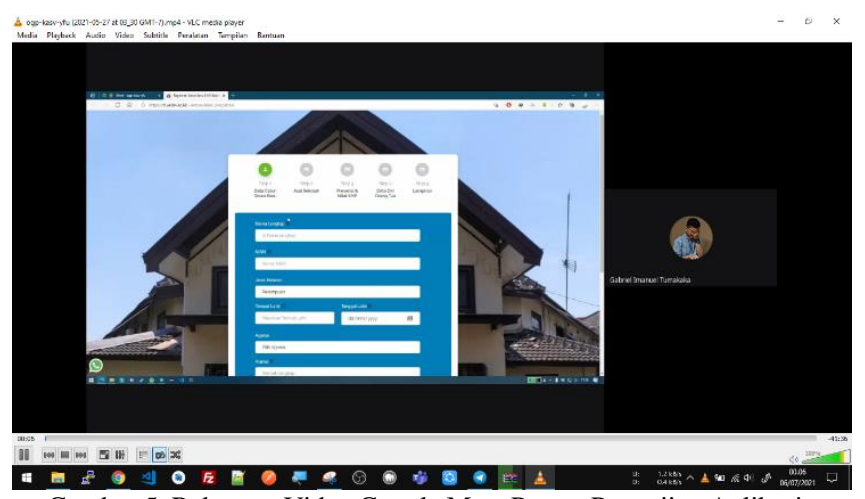

Gambar 5. Rekaman Video Google Meet Proses Pengujian Aplikasi

Proses pengujian berlangsung kurang lebih selama 231 menit atau setara dengan 3,85 jam. Dari 26 responden yang terlibat didapatkan data seperti yang tampak pada Tabel 1.

TABEL I

PENGUJIAN APLIKASI SiBARU

\begin{tabular}{|l|l|l|l|}
\hline No & Waktu Penyelesaian (detik) & $\begin{array}{l}\text { Berh } \\
\text { asil }\end{array}$ & $\begin{array}{l}\text { Platfo } \\
\text { rm }\end{array}$ \\
\hline
\end{tabular}

\begin{tabular}{|c|c|c|c|c|c|c|c|c|}
\hline & $\begin{array}{l}\text { Data } \\
\text { Calo } \\
\text { n } \\
\text { Sisw } \\
\text { a } \\
\end{array}$ & $\begin{array}{l}\text { Data } \\
\text { Asal } \\
\text { Seko } \\
\text { lah }\end{array}$ & $\begin{array}{l}\text { Data } \\
\text { Pres } \\
\text { ensi } \\
\text { dan } \\
\text { Nilai }\end{array}$ & $\begin{array}{l}\text { Data } \\
\text { Diri } \\
\text { Ora } \\
\text { ng } \\
\text { Tua } \\
\end{array}$ & $\begin{array}{l}\text { La } \\
\text { m } \\
\text { pir } \\
\text { an }\end{array}$ & $\begin{array}{l}\text { Ce } \\
k \\
\text { St } \\
\text { at } \\
\text { us } \\
\end{array}$ & & \\
\hline 1 & 86 & 23 & 60 & 125 & 48 & 29 & Ya & $\begin{array}{l}\text { Deskto } \\
\mathrm{p}\end{array}$ \\
\hline 2 & 42 & 32 & 28 & 100 & 30 & 5 & Ya & $\begin{array}{l}\text { Deskto } \\
\mathrm{p}\end{array}$ \\
\hline 3 & 88 & 27 & 20 & 133 & 36 & 7 & Ya & $\begin{array}{l}\text { Deskto } \\
\text { p }\end{array}$ \\
\hline 4 & 80 & 15 & 28 & 87 & 65 & 10 & $\mathrm{Ya}$ & $\begin{array}{l}\text { Deskto } \\
\mathrm{p}\end{array}$ \\
\hline 5 & 45 & 23 & 27 & 95 & 25 & & $\begin{array}{l}\text { Tida } \\
\mathrm{k}\end{array}$ & $\begin{array}{l}\text { Deskto } \\
\text { p }\end{array}$ \\
\hline 6 & 45 & 5 & 15 & 20 & & & $\begin{array}{l}\text { Tida } \\
\mathrm{k}\end{array}$ & $\begin{array}{l}\text { Deskto } \\
\text { p }\end{array}$ \\
\hline 7 & 194 & 21 & & & & & $\begin{array}{l}\text { Tida } \\
\mathrm{k} \\
\end{array}$ & $\begin{array}{l}\text { Deskto } \\
\mathrm{p}\end{array}$ \\
\hline 8 & 90 & 32 & 60 & 113 & 98 & 5 & Ya & $\begin{array}{l}\text { Deskto } \\
\text { p }\end{array}$ \\
\hline 9 & 78 & 27 & 50 & 102 & 75 & 10 & $\mathrm{Ya}$ & $\begin{array}{l}\text { Deskto } \\
\mathrm{p}\end{array}$ \\
\hline 10 & 59 & 20 & 38 & 93 & 72 & 9 & $\mathrm{Ya}$ & $\begin{array}{l}\text { Deskto } \\
\text { p }\end{array}$ \\
\hline 11 & 70 & 22 & 48 & 105 & 73 & 11 & $\mathrm{Ya}$ & $\begin{array}{l}\text { Deskto } \\
\mathrm{p}\end{array}$ \\
\hline 12 & 55 & 25 & 30 & 100 & 70 & 7 & Ya & $\begin{array}{l}\text { Deskto } \\
\mathrm{p}\end{array}$ \\
\hline 13 & 108 & 55 & 113 & 233 & $\begin{array}{l}11 \\
0\end{array}$ & 15 & Ya & $\begin{array}{l}\text { Deskto } \\
\mathrm{p}\end{array}$ \\
\hline 14 & 104 & 32 & 48 & 137 & 60 & 13 & $\mathrm{Ya}$ & $\begin{array}{l}\text { Deskto } \\
\mathrm{p}\end{array}$ \\
\hline 15 & 100 & 34 & 47 & 110 & 70 & & $\begin{array}{l}\text { Tida } \\
\mathrm{k}\end{array}$ & $\begin{array}{l}\text { Deskto } \\
\mathrm{p}\end{array}$ \\
\hline 16 & 113 & 29 & 39 & 138 & 43 & 4 & $\mathrm{Ya}$ & $\begin{array}{l}\text { Deskto } \\
\mathrm{p}\end{array}$ \\
\hline 17 & 187 & 97 & 199 & 195 & $\begin{array}{l}21 \\
7 \\
\end{array}$ & & $\begin{array}{l}\text { Tida } \\
\mathrm{k}\end{array}$ & Mobile \\
\hline 18 & 193 & 34 & 49 & 100 & $\begin{array}{l}11 \\
1 \\
\end{array}$ & 47 & Ya & Mobile \\
\hline 19 & 98 & 19 & 32 & 130 & 80 & 40 & $\mathrm{Ya}$ & Mobile \\
\hline 20 & 69 & 30 & 30 & 154 & 69 & 13 & $\mathrm{Ya}$ & Mobile \\
\hline 21 & 75 & 29 & 27 & 109 & 75 & 20 & $\mathrm{Ya}$ & Mobile \\
\hline 22 & 75 & 77 & 159 & 181 & $\begin{array}{l}18 \\
1\end{array}$ & & $\begin{array}{l}\text { Tida } \\
\mathrm{k}\end{array}$ & $\begin{array}{l}\text { Deskto } \\
\mathrm{p}\end{array}$ \\
\hline 23 & 112 & 41 & 76 & 256 & 48 & 11 & $\mathrm{Ya}$ & $\begin{array}{l}\text { Deskto } \\
\mathrm{p}\end{array}$ \\
\hline 24 & 84 & 38 & 47 & 202 & $\begin{array}{l}12 \\
3 \\
\end{array}$ & 6 & $\mathrm{Ya}$ & $\begin{array}{l}\text { Deskto } \\
\mathrm{p}\end{array}$ \\
\hline 25 & 107 & 19 & 43 & 197 & 68 & & $\begin{array}{l}\text { Tida } \\
\mathrm{k}\end{array}$ & $\begin{array}{l}\text { Deskto } \\
\mathrm{p}\end{array}$ \\
\hline 26 & 99 & 23 & 38 & 143 & 27 & 6 & $\mathrm{Ya}$ & $\begin{array}{l}\text { Deskto } \\
\mathrm{p}\end{array}$ \\
\hline $\begin{array}{l}\text { av } \\
\text { g }\end{array}$ & $\begin{array}{l}94.4 \\
6\end{array}$ & $\begin{array}{l}31.8 \\
8\end{array}$ & $\begin{array}{l}54.0 \\
4\end{array}$ & $\begin{array}{l}134 . \\
32\end{array}$ & $\begin{array}{l}78 . \\
08\end{array}$ & $\begin{array}{l}14 . \\
1\end{array}$ & & \\
\hline $\begin{array}{l}\mathrm{m} \\
\mathrm{ax}\end{array}$ & 194 & 97 & 199 & 256 & $\begin{array}{l}21 \\
7 \\
\end{array}$ & 47 & & \\
\hline $\begin{array}{l}\mathbf{m i} \\
\mathrm{n}\end{array}$ & 42 & 5 & 15 & 20 & 25 & 4 & & \\
\hline
\end{tabular}


Tabel I menunjukkan waktu pengisian data di setiap grup data. Terdapat 6 grup pengisian data yaitu Data Calon Siswa Baru, Asal Sekolah, Presensi dan Nilai, Data Diri Orang Tua, Lampiran, dan Cek Status Registrasi. Terdapat 7 dari 26 responden yang gagal dalam melakukan pengisian data. Artinya tingkat keberhasilan aplikasi ini digunakan adalah $74 \%$. Secara umum rata-rata waktu pengisian data adalah 382 detik atau 6,36 menit. Waktu terlama adalah 634 detik atau 10,5 menit. Waktu pengisian tercepat adalah 237 detik atau 3,95 menit. Dari data pengujian terdapat responden yang menggunakan perangkat mobile dalam melakukan input data.

Terdapat perbedaan waktu antara pengguna perangkat mobile dan desktop. Pengguna perangkat mobile menghabiskan waktu $8,86 \%$ lebih lama dibanding pengguna desktop. Hal ini cukup wajar di mana penggunaan mobile terlebih untuk pencarian file akan jauh lebih sulit dan lama dibandingkan menggunakan pc atau laptop. Untuk waktu pengisian data tercepat pada bagian cek status registrasi pada angka 4 detik saja, dan waktu terlama pengisian data terdapat pada bagian data diri orang tua yaitu 134,32 detik atau sekitar 2,23 menit.

Dari hasil pengujian telah didapatkan beberapa hal yang memerlukan perbaikan, terutama bagi pengguna yang menggunakan perangkat mobile (smartphone dan tablet). Tingkat keberhasilan $74 \%$ masih memerlukan perbaikan, dengan beberapa kendala pada pemilihan file, pengisian data yang terlalu banyak pada bagian riwayat sekolah SMP (nilai dan jumlah absen). Untuk menangani permasalahan tersebut telah ditambahkan beberapa informasi-informasi tambahan serta panduan pengisian yang lebih jelas.

Tahap selanjutnya yang akan dilakukan adalah pendampingan penggunaan terhadap pihak SMA Bopkri I Yogyakarta. Pendampingan akan dilakukan pada bulan Agustus akhir - September 2021. SiBaru diharapkan dapat digunakan pada bulan Desember 2021. Pada pendampingan akan dilakukan pelatihan pengguna admin sekolah, perwakilan Kesiswaan, perwakilan Humas dan Admisi, serta guru bidang TIK. Setelah pendampingan dan pelatihan akan diberikan kuesioner kepuasan pengguna dan kepuasan mitra.

\section{KESIMPULAN DAN SARAN}

Pengembangan aplikasi registrasi calon siswa baru untuk SMA Bopkri I telah berhasil dilakukan dalam beberapa tahap pengembangan, pengujian dan evaluasi, pemasangan dan pengelolaan sistem serta pelatihan kepada pengguna. Aplikasi yang dikembangkan sudah memenuhi semua kebutuhan-kebutuhan sistem yang telah didefinisikan, kemudian telah dilakukan pengujian dan evaluasi yang hasilnya sesuai dengan kebutuhan dari SMA Bopkri I. Tingkat keberhasilan sistem mencapai $74 \%$.

Aplikasi registrasi calon siswa baru yang dikembangkan akan digunakan pada tahun ajaran 2021/2022, sehingga masih ada waktu untuk dilakukan pelatihan kepada guru atau tenaga administrator dari SMA Bopkri I yang ditunjuk sebagai tim registrasi calon siswa baru.

Program pengabdian ini masih bisa dilanjutkan pada tahap pelatihan dan pendampingan penggunaan bagi pada guru dan tenaga administrasi SMA Bopkri I. Selain itu dimungkinkan juga pengembangan sistem baru untuk kebutuhan sekolah seperti seleksi masuk dalam bentuk online test, pengembangan sistem pendukung keputusan untuk seleksi calon siswa baru dan integrasi sistem registrasi dengan sistem-sistem lainnya yang sudah berjalan di SMA Bopkri I.

Sistem registrasi calon siswa baru yang telah dikembangkan dapat juga diimplementasikan pada sekolahsekolah lain yang masih belum memiliki sistem pendaftaran calon siswa baru yang berbasis aplikasi website.

\section{UCAPAN TERIMA KASIH}

Tim pengabdian mengucapkan terima kasih kepada Lembaga Penelitian dan Pengabdian Masyarakat (LPPM) Universitas Kristen Duta Wacana untuk segala dukungan yang diberikan untuk melakukan pengabdian ini dengan kontrak pengabdian nomor 095/D.02/LPPM/2021.

\section{DAFTAR PUSTAKA}

[1] S. Sarwindah, "Sistem Pendaftaran Siswa Baru Pada SMP N 1 Kelapa Berbasis Web Menggunakan Model UML," J. Sisfokom (Sistem Inf. dan Komputer), vol. 7, no. 2, pp. 110-115, 2018, doi: 10.32736/sisfokom.v7i2.573.

[2] S. Dewi, "Konsep Perlindungan Hukum Atas Privasi Dan Data Pribadi Dikaitkan Dengan Penggunaan Cloud Computing Di Indonesia," Yust. J. Huk., vol. 5, no. 1, pp. 22-30, 2016, doi: 10.20961/yustisia.v5i1.8712.

[3] M. Irfan Rapiansyah, "Sistem Informasi Penerimaan Siswa Baru pada SMK Al Amin Cibarusah," J. Sibernetika, vol. 5, no. 2, 2020.

[4] M. Ocka Dharma Putra and J. Dapiokta, "Perancangan Sistem Informasi Penerimaan Siswa Baru Berbasis Web Pada Sd Negeri 43 Oku," Inform. dan Teknol., vol. 1, no. 2, pp. 6-9, 2020.

[5] M. N. P. Pratama, A. Sevtiana, and D. Martha, "Penerapan Metode Simple Additive Weighting (Saw) Pada Sistem Seleksi Penerimaan Calon Siswa Baru (Studi Kasus: Smk Negeri 1 Cirebon),” J. Digit, vol. 5, no. 2, pp. 159-170, 2017, [Online]. Available: http://www.jurnaldigit.org/index.php/DIGIT/article/view/49.

[6] M. I. Dzulhaq, S. Sutarman, and S. Wulandari, "Sistem Pendukung Keputusan Penerimaan Siswa Baru Dengan Metode Simple Additive Weighting di SMK Kusuma Bangsa," J. Sisfotek Glob. vol. 7 , no. 2, pp. 51-55, 2017

[7] I. A. Nata, B. Soedijono, H. Al, and Fatta, "Dengan Metode Topsis," Penentuan Wil. Promosi Penerimaan Siswa Baru Dengan Metod. Topsis, vol. XII, no. 34, pp. 61-80, 2017.

[8] S. 2018 Anisyah, "Perancangan Sistem Informasi Registrasi 
Online,” J. SISFOKOM, vol 07, no. September, pp. 174-179, 2018.

[9] Andriansyah, I. Yuniva, and H. D. Sanjaya, "Perancangan Sistem Informasi Penerimaan Siswa Baru Berbasis Web Pada SMK Bhakti Pertiwi Kota Tangerang Mengurangi pengarsipan dokumen dari hasil penerimaan siswa baru dalam arsip buku besar .," Indones. $J$. Netw. Secur., vol. 8, no. 2, pp. 1-7, 2019.
[10] A. Frediryana and Sukadi, "Analisis Dan Perancangan Sistem Informasi Pendaftaran Mahasiswa Baru Pada Sekolah Tinggi Ilmu Tarbiyah Muhammadiyah Pacitan," J. Speed - Sentra Penelit. Eng. dan Edukasi, vol. 4, no. 1, pp. 63-72, 2012. 